\title{
Assessment of Safety Equipment Utilization Rate and Magnitude of Occupational Related Incidences Among Workers in the Ministry of Defense Construction CMC Site, Addis Ababa, Ethiopia, 2018
}

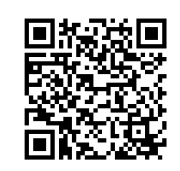

\author{
Fasil Kenea Duguma*, Kelayu Kiros, Ibrahim Hussen, Fantahun Aderaw, Alemayehu Gemechu, Terefe Tadese, \\ Bezu Denidr, Mequanint Alemayehu, Kahasye Mehari, Zeberihe Ermias and Ashenafi Hailu
}

Department of Public Health, Defense Health Science College, Addis Ababa, Ethiopia

Submission: August 22, 2019; Published: September 27, 2019

*Corresponding author: Fasil Kenea Duguma, Public Health Department, Defense Health Science College, Addis Ababa, Ethiopia

Abstract

Introduction: ILO and WHO joint Committee defined Occupational health and safety as: "Occupational health should aim at the promotion and maintenance of the highest degree of physical, mental and social well-being of workers in all occupations. Occupational health services are available only to $10-15 \%$ of the 3 billion workers of the world.

Method: Institutional based descriptive cross-sectional study was conducted. Large scale house construction site was selected by using purposive sampling method, based on the number of worker $(n=274)$ and construction units. All workers were participated in the study. Data was collected in both interview and observational approaches. SPSS 20 version computer software package was used for data entry, cleaning, coding and analysis.

Result: Health and safety information access, habit of personal protective utilizations had an association with occurrence occupational injuries. Majority of the participants $167(60.9 \%)$ were male workers, the mean age was 28.92(SD \pm 6.805$)$; $233(85 \%)$ of workers had not safety training exposure and $83(30 \%)$ of workers involve manual handling activity like pulling, pushing, carrying, and lifting. Among these 25(15.8\%) of were carrying very heavy tools greater than $50 \mathrm{~kg}$ for an average of 4 hours and above. Most of the participant handling approach were observed as it was risky to them.

Conclusion and recommendation: Behavioral factors like sleep disturbance, lack of satisfaction, alcohol consumption, smoking cigarette, poor habit of personal protective equipment was observed as main contributing factor for occupational injury. Provision of Safety training and continuous monitoring play role in reducing occupational injury

Keywords: Construction safety; Occupational health and safety; Ethiopia; Safety equipment or material; Construction worker

Abbreviations: DUCHS: Defense University College of Health Science; EC: Ethiopian Colander; ETB: Ethiopian Birr; FDR: Federal Democratic Republic of Ethiopia; GC: Gregorian Colander; GDP: Gross Domestic Product; NCA: National Construction Authority; ILO: International Labor Organization, PI: Principal Investigator, PPE: Personal Protective Equipment's; WHO: World Health Organization

\section{Introduction}

International labor organization or World Health Organization Joint Committee defined occupational health and safety as: "Occupational health should aim at: the promotion and maintenance of the highest degree of physical, mental and social well-being of workers in all occupations. The prevention of workers in their working section from risks adverse to their health and placement of workers in an occupational environment adapted to their physiological and psychological capabilities are also the objectives of occupational health [1]. Occupational injury is a death, unintentional physical damage resulting from an occupational accident; it is fatal or non-fatal injury [2,3].
Occupational health services are available only to $10-15 \%$ of the 3 billion workers of the world. In industrialized countries, the coverage varies between 15 and $90 \%$ and in developing countries between a few percent and $20 \%$ [3-5].

The role of occupational health services in most developing countries has been given less attention due to inadequate knowledge, shortage of information, lack of resources and lack of political will which can impose greater burdens for occupational injuries [6,7]. The experience and practice of occupational health service in Ethiopia is very limited. Recently, the national Ministry of Labor and Social Affairs is giving emphasis and under plan to 


\section{Civil Engineering Research Journal}

organize the service, but the baseline information on determinants of occupational injuries especially on construction work is scarce /absent for planning and implementing to prevent and control it [8]. In 2015, US bureau of labor statistic reports shows that roughly 2.9 million non-fatal workplace injuries and illnesses, of which 2.8 million were injuries in private industry employers, which occurred at a rate of 3.0 cases per 100 equivalent full-time workers [9].

According to Ethiopia labor statistics development program with ILO, improving working environment and strengthening occupational health and safety are used for enhancing work efficiency at any industry $[10,11]$ The majority of developing country like Ethiopia, occupational health and safety aspect has been given less attention and workers, who have been done in construction industry are work- related injury occur very high. This is due to illiteracy, poverty, lack of health, and safety training and information on health hazards and risks at the workplace [12]. Globally, about millions of working age group peoples are work under poor and risk environments, due to the occupational injuries and disease continue to be the leading cause of workrelated deaths [13]. Recently WHO/ILO report shows that every 15 seconds, a worker dies from occupational accident or disease [14]. Every 15 second, 153 workers and every day 6300 people die as results of occupational accident or work-related (13). The impact of these, the economic burden of occupational injury that means the direct and indirect cost 1.8\%-6\% GDP in average $4 \%$ of National Domestic Product in worldwide $[15,16]$. According to same studies, the construction industry in the world is rapidly growing at a rate of $75.5 \%$ on average. This reality is also experienced in the Ethiopian context, it reaches to $12 \%$ in the year $2014 / 15$ [16]. However, a survey was done by international commission on occupational health member from 47 industrialized and industrializing countries; the estimated coverage of workers with OSH services was only $18 \%$ [14]. The right of labor is declared with detail obligation of employers in Ethiopian labor proclamation no 377/2003 EC. The proclamation explains that employees must take appropriate steps of ranging from instructing or notifying employees concerning the hazards of their respective occupations to provide workers with protective tools, clothing and other safety equipment. But unfortunately, this legal document, according to the existing working environment and situation of daily labored, seems to have been just shelved at the ministry of social and labor affair, justice bodies and construction companies $[17,18]$. Irrespective of this, the construction industry is at its booming stage, especially in Addis Ababa. Hence, implementation of occupational health and safety rules had a major problem in developing country [19].

An occupational injury is one of the most prevalent among construction industries reports of developing countries show work-related injury are the most commonly reported occupational illness and disability. Apart from personal suffering, these conditions impose a major financial burden on the community on employers and on individual. There is less information about the prevalence and associated risk factor of work-related injuries among building construction workers population in developing countries like Ethiopia when compared to industrialized countries. Occupational morbidity, disability and death without use PPE in most developing countries including Ethiopia are becoming a serious public problem. Construction industry has been identified as one of the most hazardous industries in many parts of the world. Especially developing country like Ethiopia in which, development on housing construction on fast growing are more affected. Although, evidence based occupational health and safety services are indispensable, studies showing factors of occupational injury in most workplaces such housing construction are scarce in Ethiopia. Therefore, finding of this study may utilized and provide baseline information for Defense construction sector/bureau, help in proper usage of PPE's to prevent workrelated injury for employer, employee Defense construction sector/bureau.

This study discovers the rate personal protective equipment utilization and protecting factors in Addis Ababa Ethiopian Defense construction industries. Different investigation reported that low educational status, low monthly salary, low working experience ( 5 years or less) on present job were common risk factor for work-related injuries [20-22]. Most occupational health and safety studies conducted in developing countries also revealed that increased educational levels in factory have been associated with decreased work-related injuries $[23,24]$. However, across sectional status in Addis Ababa shows educational status of the workers has not significantly associated with magnitude of occupational injuries [20]. Education is more likely to increase workers safety and health practice that can prevent them from occupational injuries $[25,26]$. Workers salary per month was found to be significantly related to injury occurrence. Workers with low income could have more hazardous job in which may not use protective clothing. Workers with good salaries are usually highly educated have supervisory jobs and have less exposure to job hazards [27].

Many studies concluded hours worked per week, health and safety information, workplace supervision health and safety training showed a significant association with work and workrelated injuries $[21,23,28,29]$. An increasing number of studies have considered job satisfaction and regular supervision of workplace as pervasive and influential factors in the occurrence of work-related injuries in the work environment. Study done in France indicated that work accidents have been associated with alcohol consumption [30]. Study done in our country Afar regional state workers who were used drink alcohol were more likely to be injured than those who do not consume alcohol but no significant association between chat chewing and cigarette smoking with occurrence of occupational injuries [29].

Also, study conducted in Gondar University among the construction workers included that awareness among workers 
regarding dangers and risks at workplace use of personal protective equipment, and good personal hygiene practice to minimize unnecessary exposure to work site contaminants was found to be important to decrease the occupational injury problems and improve the health status of workers [31]. Most study show that the leading cause of occupational injury among construction workers are falling ground level, struck by an object, cutting by sharp object and slipping [21, 23, 25, 31].

Questionnaires-based survey conducted in Ethiopia, Gondar among construction workers show that the major occupational problem are skin disorder $16 \%$ eye problem and headache, $15 \%$ muscular skeletal problem and harm by sharp instrument
$14 \%$ [32]. Finally, the prevalence and factors that contribute the occurrence of injury in workplace in Ethiopia will studied. And, the availability and utilization PPE among construction worker are not studied. So, this study will provide baseline information for policy makers to design strategy to give priority to prevention and control of occupational injuries to have healthy workforce and sound economic development by availability of PPE to workers and regular supervision on the [33]work site for proper utilization of PPE, training of pre-work and after work. The result of this research is expected to be important for practitioners and researchers on how to deal with incorporate and identify problems related to ergonomic aspects to assess work-related injuries in the construction industry Figure 1.

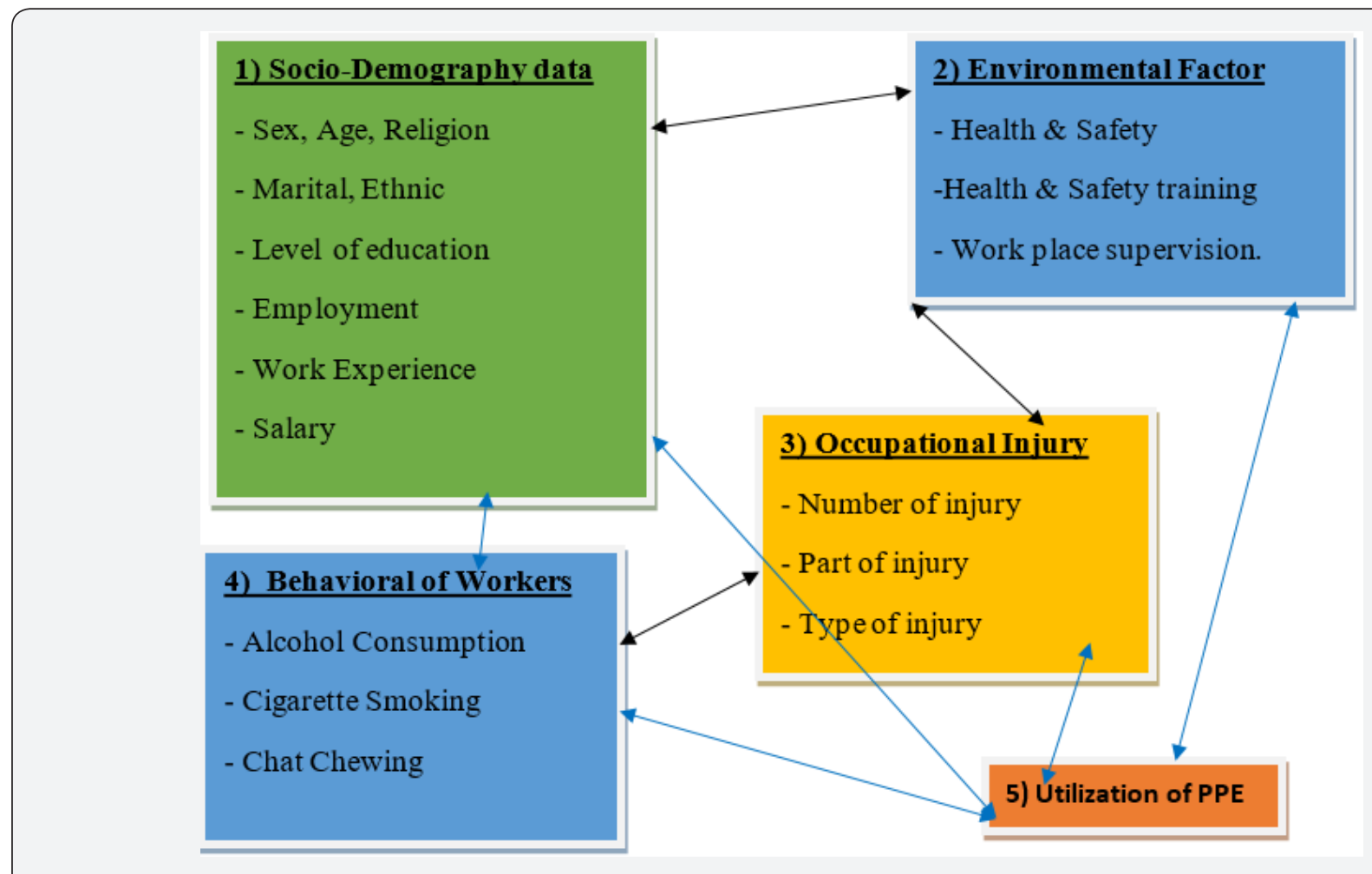

Figure 1: Conceptual framework of the study.

\section{Methodology}

\section{Study design}

Institutional based descriptive cross-sectional study method was used

Study area and period: The study was conducted in Addis Ababa (Capital city of Ethiopia). From Feb 26 - Mar 19/2018 GC, in "CMC" site Defense construction, which is Defense Foundation house construction. Addis Ababa city has a total population of $3,338,569$, projected from the 2015 population census (CSA 2007 EC). The city is divided into ten sub-cities. Defense construction bureau has 29 construction Project as hole of the country, from this the 7 large construction projects are in Addis Ababa, CMC site is one of the largest construction project contains 17 block of ground pulse 7 and 9 . The choice of this sector was based on the size of the project and number of worker in the project so based on this factors CMC project site was selected as main study site.

\section{Source of population}

All workers who engaged in Defense construction firm, CMC Defense Foundation house construction, Addis Ababa.

\section{Study population}

Selected workers, who was directly involved in the building construction project considered as a part of study population.

\section{Sampling size determination}

All employees who involved in 17 block construction workers, working as the masons, Carpenters and roofers, Plumbers and electricians, finishing worker, Helpers and daily laborers were included in the study to assess the rate of safety material utilization; 
and experienced occupational injury within the past 12 months, and last 2 weeks workers who never experienced occupational injury within the working site. employee as supervisors, trackers, and other managerial working area were excluded from the study assuming that they were less exposed for occupational injury.

The total number of workers in the selected study site were $\leq 2,000$ out of this 800 population was calculated using formula of a single population proportion, so the sample size was 274 considering, data was continuous and at confidence interval 95\%, marginal of error 5\% and considering 5\% non-response rate. There are 29 project with $\geq 20,000$ workers in Defense construction sector, from these only one site was included in our study, (3.5\%) was selected for study according to our randomly selection, $3.5 \%$ was inadequate for analysis and reporting, but the selected sites have uniform PPE requirements because they had one similar experience. Our site had been registered by Addis Ababa city and certified by NCA. In the site 274 participants was select by the interval of $3^{\text {th }}$ to participate in the study because the number of construction workers in one site will almost the same.

NB: $-n=z^{2} p(1-p) / w^{2}=(1.96)^{2} \times(0.5 \times 0.5) /(0.05)^{2}=3.84 \times$ $0.25 / 0.0025$

$$
=404=0.96 \div 0.0025=384=384+5 \% \text { non-response }=384+19.2
$$

1. Finite population correction formula if $\mathrm{N}=800 \mathrm{n}=\mathrm{n} /$ $(1+n / N)$

2. $384 /(1+384 / 800)$

3. $384 /(800+384 / 800)$

4. $384 /(1184 / 800)=384 \div 1.48=259.5=260$

5. $261 \times 5 \%$ non-response

6. $261+13=274$ will be final sample size.

\section{Sampling procedure}

Sample size (n) was calculated by using one population proportion formulas by considering used of PPE and unused of PPE among the construction workers. Out of 800 workers 274 workers was sample size by the interval of $3^{\text {th }}$ was select by using randomly sampling method. Project 16-01B and Project 14-01B working department which include in the study, the total sample was the construction site and their worker population size was calculated based on availed participant at the observation time. Pre-taste and structural interview questionnaire and observational check list was used to collect the data. Finally, each study subject was selected by using random sampling technique on the workers work site.

\section{Data collection}

Data were collected by using pre-taste and structured Amharic questionnaire face to face interview approach. Training was given for both the facilitators, supervisors at the time of data collection. The training includes briefing on the general objective of the study, discussing the content of the questionnaires and type of information needed to be answered. The questionnaire focused on the Socio- demographic, utilization and availability of PPE, behavior of the workers, environmental risk factors, occupational injury, and job stress assessment tools. We used observation check list for cross checking mechanism for data quality. Data were collected by six BSc public health profession or group members, which were used to determine on prevention of occupational injury within the construction area.

\section{Operational definition}

Personal Protective Equipment: -Utilization of a material uses by worker who work in a construction worker protection against health and safety hazard. Include items success as gloves, safety glasses, ear plug, shoes/boots, hard hats, respiratory or coveralls, full body suits that necessary to be worn during a activity [27].

Occupational Injury: Any physically injury sustained on worker in construction within the performance of his or her work and absent from work four or more days from workplace [27].

Health and Safety training: A Training gave to a worker about health and safeties.

Occupation Health Risk: Any source of potential damage, harm or adheres health effects on something or someone under certain conditions at work.

Permanent employee: -Any contract of employment between employee and employer concluded for an indefinite period [25].

Temporary employee: Any employment contract between employee and employer made for define period [25].

Cigarette Smoker: Any employee who were smoking one cigarette per day or occasional for at least 1 years.

Alcohol drinker: An employee who drinks alcohol at least five drinks per week for men for at least 1 year, and two drinks pet week for women for at least 1 year.

\section{Study variable}

\section{Dependent variable: Utilization of safety material/PPE}

\section{Independent variable}
a. Socio-Demographic data.
b. Availability of PPE.
c. Behavior of the worker
d. Environmental factor
e. Job stress assessment tool.

\section{Inclusion and Exclusion criteria}

\section{Inclusion criteria}

I. Who were18 years and above.

II. Who were works 3 months and above. 


\section{Civil Engineering Research Journal}

III. Who were willing to participate in the study.

IV. Who practically construction worker.

\section{Exclusion criteria}

A. Those age below 18 years.

B. Those who unwilling to participate in the study

C. Those who were working below 3 months in the study site

D. those who not practically construction worker.

\section{Data processing and analysis}

Data entry and the analysis were conducted by using SPSS version 16 software package for data management and analysis. The descriptive statistics such as frequency, percent, mean, and median were employed for most variables.

\section{Data quality control management}

The questionnaire was first prepared originally in English and translated to Amharic and then back to English to verify the consistency and content validity. Finally, Amharic version was used. All the research team was involved in data collection after training. The training was focused on data collection instrument, field method inclusion-exclusion criteria and record keeping issues. The interview questionnaire was pre-tasted on 5\% [14] respondents in Defense head quarter sub construction old airport,
Addis Ababa, LIDETA sub-city, to identify potential problems, unanticipated interpretation and objection; based on the finding of pretests some modification was done on the questionnaire before the actual data collection.

\section{Ethical consideration}

This study was carried out after obtained ethical clearance from Defense University collage of health science/IERC of the college. Permission to conduct this study was secured from Defense construction bureau and from study construction site officially. Oral consent from each subject was obtained after clear explanation on the purpose of the study. Participant was also informed as they had full right to discontinue or refuses to participate in the study. confidentiality, autonomy, privacy, total time taken was informed and secured.

\section{Results}

\section{Socio demographic characteristics}

A total of 274 participants were interviewed for this study, the total participant $167(60.9 \%)$ were male workers, under the age of 30 years $181(66.1 \%$ ) and the mean age 28.92(SD \pm 6.805$)$, regarding to marital status of workers majority of them were single 155(56.6\%), about educational level of worker 84(30.7\%) completed primary level Table 1, 157(57.3\%) are temporary employed workers and about 78(28.5\%) were above or 3 months' work experience, the mean of monthly salary of the workers were 3000.81(SD \pm 1824.291$)$ Figure 2 and Figure 3.

Table1: Selected Socio-demographic determinant of utilization of PPE among Defense construction worker, Defense foundation house construction, CMC site, Addis Ababa, Ethiopia, March 2018.

\begin{tabular}{|c|c|c|c|}
\hline Variable & Valid & Frequency(f) & Precent (\%) \\
\hline \multirow{3}{*}{ Sex of Respondent $(n=274)$} & Male & 167 & 60.9 \\
\hline & Female & 107 & 39.1 \\
\hline & Total & 274 & 100 \\
\hline \multirow{5}{*}{ Age category $(n=274)$} & $<=20$ & 1 & 0.4 \\
\hline & $21-30$ & 191 & 69.7 \\
\hline & $31-40$ & 63 & 23 \\
\hline & $41-50$ & 19 & 6.9 \\
\hline & Total & 274 & 100 \\
\hline \multirow{7}{*}{$\begin{array}{l}\text { Educational status of respondent } \\
\qquad(\mathrm{n}=274)\end{array}$} & Illiterate & 14 & 5.1 \\
\hline & Read and write & 70 & 25.5 \\
\hline & Primary School (1-8) & 84 & 30.7 \\
\hline & Secondary school (9-12) & 65 & 23.7 \\
\hline & Technical school & 35 & 12.8 \\
\hline & First degree and Above & 6 & 2.2 \\
\hline & Total & 274 & 100 \\
\hline \multirow{6}{*}{$\begin{array}{l}\text { Marital status of Respondent } \\
\qquad(\mathrm{n}=274)\end{array}$} & Married & 102 & 37.2 \\
\hline & Single & 155 & 56.6 \\
\hline & Divorced & 2 & 0.7 \\
\hline & Widowed & 8 & 2.9 \\
\hline & Separated & 7 & 2.6 \\
\hline & Total & 274 & 100 \\
\hline
\end{tabular}




\section{Civil Engineering Research Journal}

\begin{tabular}{|c|c|c|c|}
\hline \multirow{3}{*}{$\begin{array}{l}\text { Employer condition of Respondent } \\
\qquad(\mathrm{n}=274)\end{array}$} & Temporarily & 157 & 57.3 \\
\hline & Permanent & 117 & 42.7 \\
\hline & Total & 274 & 100 \\
\hline \multirow{4}{*}{$\begin{array}{l}\text { Work Experience of Respondent } \\
\qquad(n=274)\end{array}$} & $>3$ months & 78 & 28.5 \\
\hline & 4 month - 5 years & 137 & 50 \\
\hline & $>5$ Years & 59 & 21.5 \\
\hline & Total & 274 & 100 \\
\hline \multirow{5}{*}{$\begin{array}{l}\text { Monthly Income category of } \\
\text { Respondent }(n=274)\end{array}$} & $<1000$ birr & 3 & 1.1 \\
\hline & $1001-2000$ birr & 156 & 56.9 \\
\hline & 2001-5000 birr & 62 & 23 \\
\hline & > 5001 birrs & 53 & 19 \\
\hline & Total & 274 & 100 \\
\hline
\end{tabular}

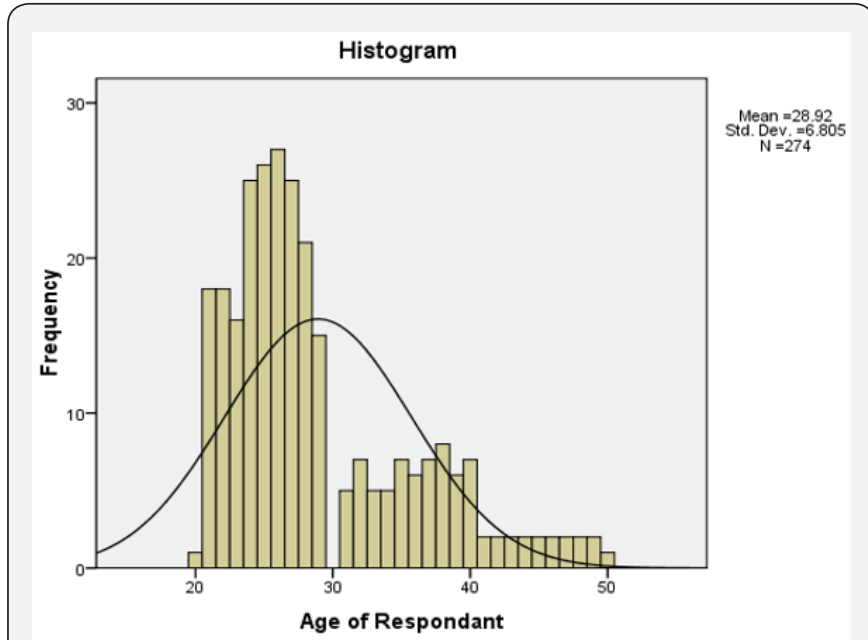

Figure 2: Distribution of respondent age by age category Defence construction, Defence foundation house construction, CMC site, Addis Ababa, Ethiopia, March 2018.

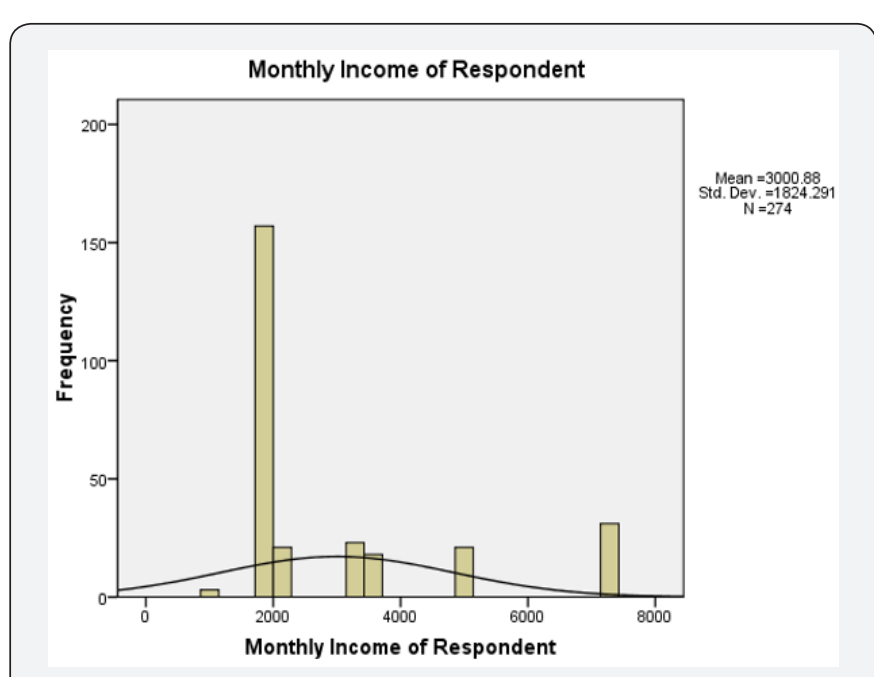

Figure 3: Distribution of respondent monthly income Defence construction, Defence foundation house construction, CMC site, Addis Ababa, Ethiopia, March 2018.

\section{Availability and utilization of personal protective equipment}

Table2: Availability and utilization of PPE and safety training level of Defense construction worker, Defense foundation house construction CMC site, Addis Ababa, Ethiopia, March 2018.

\begin{tabular}{|c|c|c|c|}
\hline Study variable & Answer variable & Frequency(f) & Percent (\%) \\
\hline \multirow{3}{*}{ Use of PPE Respondent on work } & No & 82 & 29.9 \\
\hline & Yes & 192 & 70.1 \\
\hline & Total & 274 & 100 \\
\hline \multirow{8}{*}{$\begin{array}{l}\text { Type of material Respondent use } \\
\qquad(\mathrm{n}=192)\end{array}$} & Glove & 27 & 9.9 \\
\hline & Ear plug & 6 & 2.2 \\
\hline & Mask & 5 & 1.8 \\
\hline & Helmet & 110 & 40.1 \\
\hline & All body protection & 19 & 6.9 \\
\hline & Boots/shoe & 9 & 3.3 \\
\hline & Face shield & 16 & 5.8 \\
\hline & Total & 192 & 70.1 \\
\hline \multirow{3}{*}{ All time use of PPE (n=192) } & No & 77 & 28.1 \\
\hline & Yes & 115 & 42 \\
\hline & Total & 192 & 70.1 \\
\hline
\end{tabular}




\section{Civil Engineering Research Journal}

\begin{tabular}{|c|c|c|c|}
\hline \multirow{6}{*}{$\begin{array}{l}\text { Reasons of Not use proper PPE of } \\
\text { Respondent }(n=159)\end{array}$} & Lack of comfort & 51 & 18.6 \\
\hline & To save time & 17 & 6.2 \\
\hline & Not think aware of risk & 43 & 15.7 \\
\hline & Carelessness & 11 & 4 \\
\hline & No access & 37 & 13.5 \\
\hline & Total & 159 & 58 \\
\hline \multirow{4}{*}{$\begin{array}{l}\text { Supply of PPE for Respondent } \\
\qquad(\mathrm{n}=192)\end{array}$} & From Institution & 140 & 51.1 \\
\hline & Bought myself & 44 & 16.1 \\
\hline & From NGO & 8 & 2.9 \\
\hline & Total & 192 & 70.1 \\
\hline \multirow{3}{*}{$\begin{array}{l}\text { Training of job before engaged to } \\
\text { the job }(n=274)\end{array}$} & No & 203 & 74.1 \\
\hline & Yes & 71 & 25.9 \\
\hline & Total & 274 & 100 \\
\hline \multirow{3}{*}{$\begin{array}{l}\text { Training of job after engaged to the } \\
\text { job }(n=274)\end{array}$} & No & 207 & 75.5 \\
\hline & Yes & 67 & 24.5 \\
\hline & Total & 274 & 100 \\
\hline
\end{tabular}

The result showed that half of the respondents utilize PPE on duty 192(70.1\%), participant affirmed availability one or two of the following PPE, safety boots $9(3.3 \%), 110(40.1 \%)$ helmet, heavy duty gloves $27(9.9 \%)$, ear plug $6(2.2 \%)$, other equipment respectively while the remaining (45.5\%). Affirmed the availability of among PPE utilize on duty of respondent $115(42.0 \%)$ were
Table 2 used all the time. The majority worker reason for not use PPE were not fill comfort 50(18.2\%) and lack of awareness of risk 43(15.7\%). Among PPE user on duty respondent above 50\% of PPE supplied by the institution and the rest bought by workers themselves Figure 4 and Figure 5.

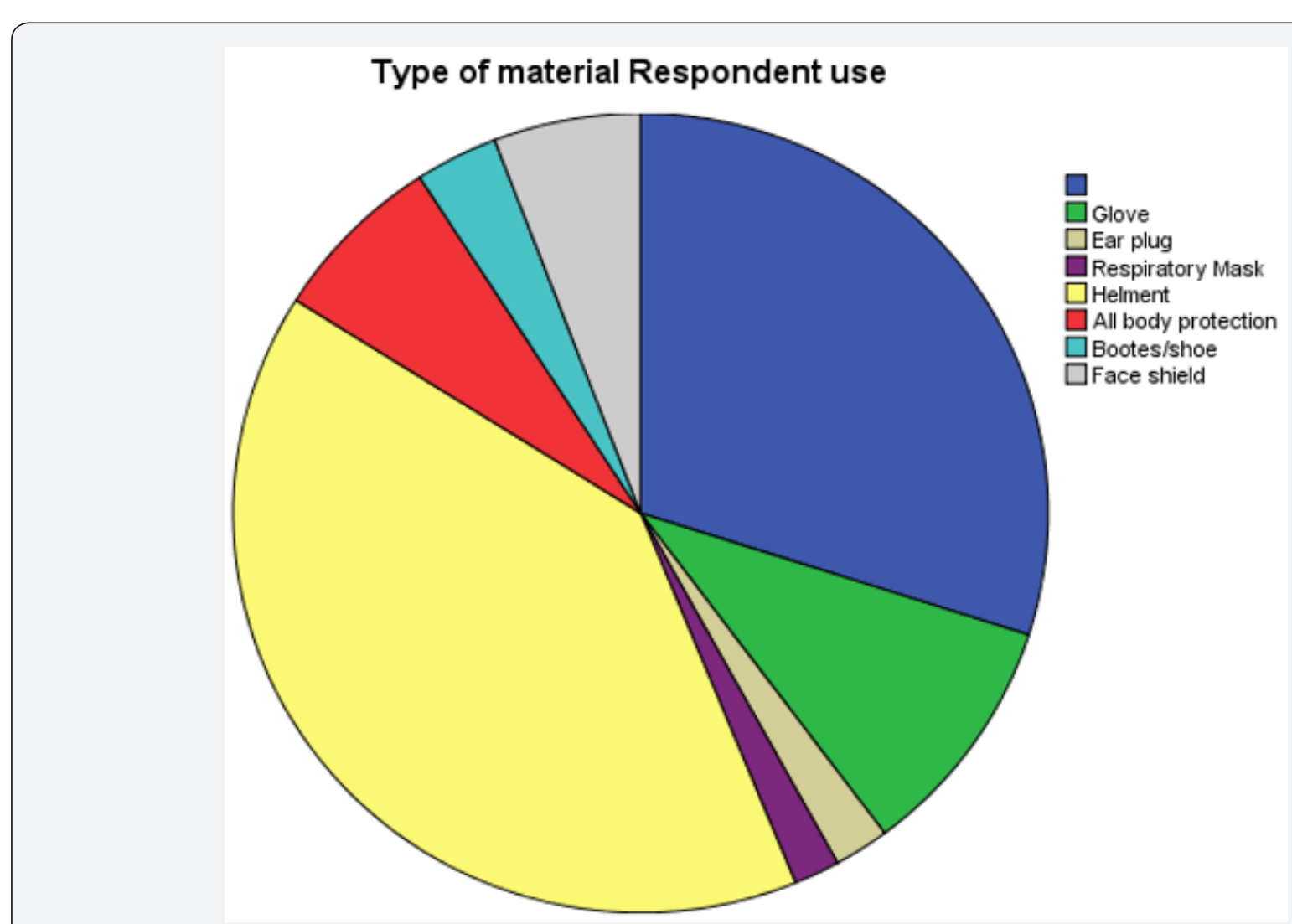

Figure 4: Type of PPE used by Defence construction, Defence foundation house construction workers, CMC site, Addis Ababa, Ethiopia, March 2018. 


\section{Resons of Not use proper PPE of Respondent}

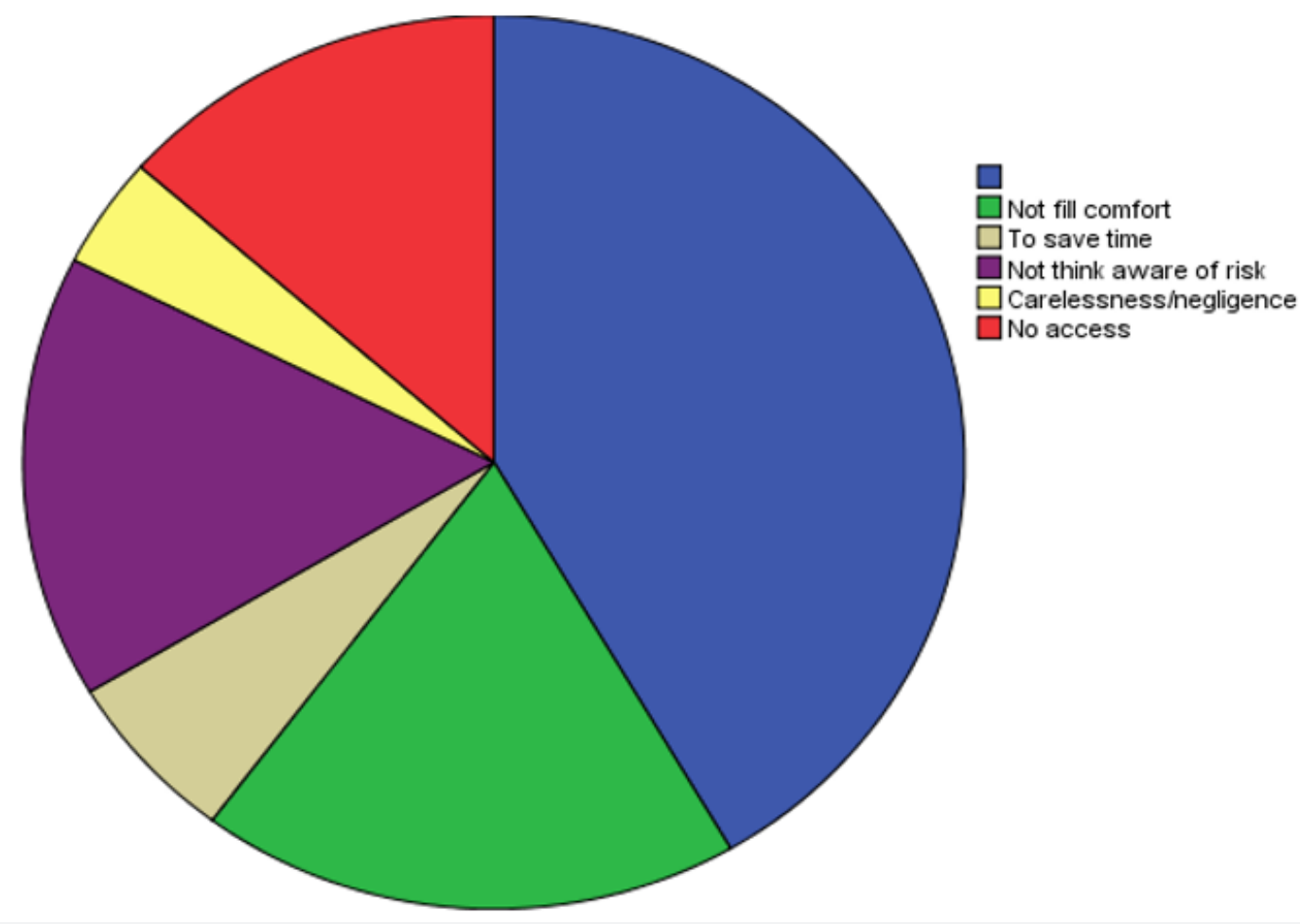

Figure 5: Reasons of not used proper PPE of respondent Defence construction, Defence foundation house construction workers, CMC site, Addis Ababa, Ethiopia, March 2018.

\section{Occupational injury related issue}

The total magnitude of occupational injury in the last 12 months was $37(13.5 \%)$, above half of respondent $23(8.4 \%)$ exposed at least once. In the last 2 weeks were $11(4.0 \%)$ were exposed at least one times suffered form of injury and did not used any PPE's. Finger 20(7.3\%) were the most injured body part of respondent. the report shows that types of accident occur in workers were hurt by struck against object 23(8.4\%), struck by object $12(4.4 \%)$ and Nile injury $8(2.9 \%)$. The main reason of injury occurrence was due to not using PPE 11(4.0\%). Among the total injured worker $10(3.6 \%)$ were visited hospital and $6(2.2 \%)$ of worker were absent from work for more than 12 hours because of the injury Table 3 .

Table 3: Distribution of injury, body part and type of injury during last 12 months, and the last 2 weeks among Defense construction, Defense foundation house construction, CMC site, Addis Ababa, Ethiopia, March 2018.

\begin{tabular}{|c|c|c|c|}
\hline Study variable & Answer variable & Frequency(f) & Percent (\%) \\
\hline \multirow{3}{*}{$\begin{array}{c}\text { Injury of respondent in the last } 12 \\
\text { months }\end{array}$} & No & 237 & 86.5 \\
\hline & Yes & 37 & 13.5 \\
\hline & Total & 274 & 100 \\
\hline \multirow{4}{*}{$\begin{array}{l}\text { Number of injury of respondent for } \\
\text { the last } 12 \text { months }(n=37)\end{array}$} & 1 times & 23 & 8.4 \\
\hline & 2 times & 10 & 3.6 \\
\hline & $3 \&$ above & 4 & 1.5 \\
\hline & Total & 37 & 13.5 \\
\hline \multirow{3}{*}{$\begin{array}{l}\text { Injury of respondent for the last } \\
2 \text { weeks }\end{array}$} & No & 255 & 93.1 \\
\hline & Yes & 19 & 6.9 \\
\hline & Total & 274 & 100 \\
\hline \multirow{3}{*}{$\begin{array}{l}\text { Number of injury respondent for } \\
\text { the last } 2 \text { weeks }(n=19)\end{array}$} & 1 times & 11 & 4 \\
\hline & 2 times & 4 & 1.5 \\
\hline & $3 \&$ above & 4 & 1.5 \\
\hline
\end{tabular}




\section{Civil Engineering Research Journal}

\begin{tabular}{|c|c|c|c|}
\hline \multirow{8}{*}{$\begin{array}{l}\text { Affected body part of respondent } \\
\qquad(\mathrm{n}=56)\end{array}$} & Eye & 9 & 3.3 \\
\hline & Tooth & 8 & 2.9 \\
\hline & Finger & 20 & 7.3 \\
\hline & Leg & 8 & 2.9 \\
\hline & Toe & 4 & 1.5 \\
\hline & Upper arm & 2 & 0.7 \\
\hline & Lower & 5 & 1.8 \\
\hline & Total & 56 & 20.4 \\
\hline \multirow{7}{*}{ Type of accident $(n=56)$} & Falling from height & 9 & 3.3 \\
\hline & Struck by object & 12 & 4.4 \\
\hline & Struck against object. & 23 & 8.4 \\
\hline & Hit by falling object & 3 & 1.1 \\
\hline & Nile injury & 8 & 2.9 \\
\hline & Falling at ground & 1 & 4 \\
\hline & Total & 56 & 20.4 \\
\hline \multirow{8}{*}{$\begin{array}{l}\text { Reason of respondent injury } \\
\qquad(\mathrm{n}=56)\end{array}$} & I was new for the work & 5 & 1.8 \\
\hline & Thinking private affairs & 4 & 1.5 \\
\hline & Medical problem & 4 & 1.5 \\
\hline & Beyond Un control & 12 & 4.4 \\
\hline & It is working behaviors & 15 & 5.5 \\
\hline & Improper use of PPE & 11 & 4 \\
\hline & I don't remember & 5 & 1.8 \\
\hline & Total & 56 & 20.4 \\
\hline \multirow{4}{*}{ Work site of respondent $(n=274)$} & At height & 33 & 12 \\
\hline & At ground & 29 & 9.5 \\
\hline & Both & 215 & 78.5 \\
\hline & Total & 274 & 100 \\
\hline \multirow{3}{*}{$\begin{array}{l}\text { Hospitalization of respondent due } \\
\text { to injury }(\mathrm{n}=56)\end{array}$} & No & 46 & 16.8 \\
\hline & Yes & 10 & 3.6 \\
\hline & Total & 56 & 100 \\
\hline \multirow{4}{*}{$\begin{array}{l}\text { Length of respondent } \\
\text { hospitalization }(\mathrm{n}=10)\end{array}$} & 12 hours & 6 & 2.2 \\
\hline & 1 week & 1 & 0.4 \\
\hline & 1 month & 3 & 1.1 \\
\hline & Total & 10 & 3.6 \\
\hline
\end{tabular}

\section{Working environment related variable}

About 274(100\%) was worked less or equal 8 hours per day/48hrs per week, 217(79.2\%) of workers were not done regular health and safety supervision of workplace. 233(85\%) of worker did not had safety training in connection with new employment, equipment, or work process, and 83(30.3\%) of workers involve manual handling activity like Pulling, Pushing, carrying, and lifting. Among those 30(12.0\%) of were carrying medium weight, $5(1.8 \%)$ were carrying very heavy (greater than $50 \mathrm{~kg}$ ) on average for 4 hours and above Table 4. 


\section{Civil Engineering Research Journal}

Table 4: Work environment related variable among Defense construction, Defense foundation house construction, CMC site, Addis Ababa, Ethiopia, March 2018.

\begin{tabular}{|c|c|c|c|}
\hline Study variable & Response variable & Frequency(f) & Percent (\%) \\
\hline \multirow{2}{*}{$\begin{array}{l}\text { Work hours per week of } \\
\text { respondent }(n=274)\end{array}$} & Hours & $8 \mathrm{hrs}$ & 100 \\
\hline & Total & 274 & 100 \\
\hline \multirow{3}{*}{$\begin{array}{l}\text { Regular health and safety } \\
\text { supervision or respondent } \\
(\mathrm{n}=274)\end{array}$} & Yes & 57 & 20.8 \\
\hline & No & 217 & 79.2 \\
\hline & Total & 274 & 100 \\
\hline \multirow{3}{*}{$\begin{array}{l}\text { Safety training of new employment } \\
\text { equipment or work proceed of } \\
\text { respondent }(n=274)\end{array}$} & Yes & 41 & 15 \\
\hline & No & 233 & 85 \\
\hline & Total & 274 & 100 \\
\hline \multirow{3}{*}{$\begin{array}{l}\text { Manual handling activity (pulling, } \\
\text { pushing, carrying, and lifting of } \\
\text { respondent }(\mathrm{n}=274)\end{array}$} & Yes & 83 & 30.3 \\
\hline & No & 191 & 69.7 \\
\hline & Total & 274 & 100 \\
\hline \multirow{5}{*}{$\begin{array}{l}\text { Average weight handled per day of } \\
\text { respondent }(\mathrm{n}=83)\end{array}$} & Light $(<5 \mathrm{~kg})$ & 20 & 7.3 \\
\hline & Medium $(6-25 \mathrm{~kg})$ & 33 & 12 \\
\hline & Heavy (25-50 kg) & 25 & 9.1 \\
\hline & Very heavy (>50 kg) & 5 & 1.8 \\
\hline & Total & 83 & 30.3 \\
\hline \multirow{4}{*}{$\begin{array}{l}\text { Average hours spend handled } \\
\text { weight per day of respondent }\end{array}$} & Not $>2 \mathrm{hrs}$ & 25 & 9.1 \\
\hline & $2-4 \mathrm{hrs}$ & 15 & 5.5 \\
\hline & $4 \mathrm{hrs}$ and above & 43 & 15.7 \\
\hline & Total & 83 & 30.3 \\
\hline \multirow{3}{*}{$\begin{array}{l}\text { Work concentration of respondent } \\
\qquad(\mathrm{n}=274)\end{array}$} & Yes & 230 & 83.9 \\
\hline & No & 44 & 16.1 \\
\hline & Total & 274 & 100 \\
\hline \multirow{3}{*}{$\begin{array}{l}\text { Vibrating tools of workplace of } \\
\text { respondent }(n=274)\end{array}$} & Yes & 34 & 12.4 \\
\hline & No & 240 & 87.6 \\
\hline & Total & 274 & 100 \\
\hline \multirow{4}{*}{$\begin{array}{l}\text { How long work per day with } \\
\text { vibrating tools of respondent }\end{array}$} & Not $>2 \mathrm{hrs}$ & 6 & 2.2 \\
\hline & $2-4 \mathrm{hrs}$ & 23 & 8.4 \\
\hline & 4hrs and above & 5 & 1.8 \\
\hline & Total & 34 & 12.4 \\
\hline \multirow{3}{*}{$\begin{array}{l}\text { Machine with always guarded or } \\
\text { installed with safety devices of } \\
\text { respondent }(\mathrm{n}=274\end{array}$} & No & 265 & 96.7 \\
\hline & Yes & 9 & 3.3 \\
\hline & Total & 274 & 100 \\
\hline \multirow{3}{*}{$\begin{array}{l}\text { Machine maintained immediately } \\
\text { when or old unsafe for respondent }\end{array}$} & No & 5 & 1.7 \\
\hline & Yes & 4 & 1.6 \\
\hline & Total & 9 & 3.3 \\
\hline
\end{tabular}

\section{Behavioural Associated Variables}

Among the total respondent only $6(2.2 \%)$ smoke cigarette,
$22(8 \%)$ drink alcohol and $6(2.2 \%)$ chew chat, $7(2.6 \%)$ had sleeping disorder Table 5. 


\section{Civil Engineering Research Journal}

Table 5: Behavioural Associated Variables among Defense construction, Defense foundation house construction, CMC site, Addis Ababa, Ethiopia, March 2018

\begin{tabular}{|c|c|c|c|}
\hline Study variable & Response variable & Frequency(f) & Percent (\%) \\
\hline \multirow{3}{*}{ Smoking of respondent $(\mathrm{n}=274)$} & No & 268 & 97.8 \\
\hline & Yes & 6 & 2.2 \\
\hline & Total & 274 & 100 \\
\hline \multirow{3}{*}{$\begin{array}{l}\text { Smoking character of/number of } \\
\text { smoking of respondent }(n=6)\end{array}$} & Every day & 1 & 0.4 \\
\hline & Occasional & 5 & 1.8 \\
\hline & Total & 6 & 2.2 \\
\hline \multirow{3}{*}{ Drinks of respondent(n=274) } & No & 252 & 92 \\
\hline & Yes & 22 & 8 \\
\hline & Total & 274 & 100 \\
\hline \multirow{4}{*}{$\begin{array}{l}\text { Number of drink of respondent } \\
\qquad(\mathrm{n}=22)\end{array}$} & Every day & 2 & 0.7 \\
\hline & 1-3 day/week & 2 & 0.7 \\
\hline & Occasional & 18 & 6 \\
\hline & Total & 22 & 8 \\
\hline \multirow{3}{*}{$\begin{array}{l}\text { Chewing chat of respondent } \\
\qquad(\mathrm{n}=274)\end{array}$} & No & 267 & 97.4 \\
\hline & Yes & 7 & 2.6 \\
\hline & Total & 274 & 100 \\
\hline \multirow{4}{*}{$\begin{array}{l}\text { Number of chat chewing of } \\
\text { respondent }(n=7)\end{array}$} & Every day & 0 & 0 \\
\hline & 1-3 day/week & 1 & 0.4 \\
\hline & Occasional & 6 & 2.2 \\
\hline & Total & 7 & 2.6 \\
\hline \multirow{3}{*}{$\begin{array}{l}\text { Sleeping disorder on work of } \\
\text { respondent }(n=274)\end{array}$} & No & 267 & 97.4 \\
\hline & Yes & 7 & 2.6 \\
\hline & Total & 274 & 100 \\
\hline \multirow{5}{*}{$\begin{array}{l}\text { Reason of sleeping disorder of } \\
\text { respondent }(n=7)\end{array}$} & Working $>8 \mathrm{hrs}$ & 2 & 0.7 \\
\hline & Working in evening & 2 & 0.7 \\
\hline & $\begin{array}{l}\text { Trying of work more than on task } \\
\text { at time }\end{array}$ & 2 & 0.7 \\
\hline & Excessive heat & 1 & 0.4 \\
\hline & Total & 7 & 2.6 \\
\hline
\end{tabular}

\section{Job stress Assessment tool}

Among the total respondent $41(15 \%)$ workers were not satisfied on the job/works. 93(33.9\%) of respondent s were said as they had hurry and excessive work load, $90(32.8 \%)$ of worker were consider work situation as danger, $179(65.3 \%)$ of respondent consider the job as it was dangers for their life, and $274(100.0 \%)$ of respondent stated that hazard sign was not displayed at work site Table 6.

Table 6: Job stress Assessment tool among Defense construction, Defense foundation house construction, CMC site, Addis Ababa, Ethiopia, March 2018.

\begin{tabular}{|c|c|c|c|}
\hline Study variable & Response variable & Frequency(f) & Percent (\%) \\
\hline \multirow{3}{*}{$\begin{array}{c}\text { Job difficulty of respondent } \\
(\mathrm{n}=274)\end{array}$} & Yes & 41 & 15 \\
\cline { 2 - 4 } & No & 233 & 85 \\
\cline { 2 - 4 } & Total & 274 & 100 \\
\cline { 2 - 4 } $\begin{array}{c}\text { Why works difficulty to } \\
\text { respondent (n=41) }\end{array}$ & I work over 8hrs & 24 & 3.8 \\
\cline { 2 - 4 } & I have work rotation & 7 & 2.6 \\
\cline { 2 - 4 } & I have no specific W. & 41 & 15 \\
\hline
\end{tabular}




\section{Civil Engineering Research Journal}

\begin{tabular}{|c|c|c|c|}
\hline \multirow{3}{*}{$\begin{array}{l}\text { Hurry due to excessive workload of } \\
\text { respondent }(n=274)\end{array}$} & Yes & 93 & 33.9 \\
\hline & No & 181 & 66.1 \\
\hline & Total & 274 & 100 \\
\hline \multirow{3}{*}{$\begin{array}{l}\text { Boring and monotonous } \\
\text { of construction worker for } \\
\text { respondent ( } \mathrm{n}=274)\end{array}$} & Yes & 90 & 32.8 \\
\hline & No & 184 & 67.2 \\
\hline & Total & 274 & 100 \\
\hline \multirow{3}{*}{$\begin{array}{l}\text { Work full danger for respondent } \\
\qquad(\mathrm{n}=274)\end{array}$} & Yes & 179 & 65.3 \\
\hline & No & 95 & 34.7 \\
\hline & Total & 274 & 100 \\
\hline \multirow{3}{*}{$\begin{array}{l}\text { Safety danger and health risk of } \\
\text { respondent }\end{array}$} & Yes & 21 & 7.7 \\
\hline & No & 253 & 92.3 \\
\hline & Total & 274 & 100 \\
\hline \multirow{3}{*}{$\begin{array}{l}\text { Hazard sign properly at work site } \\
\text { for respondent }\end{array}$} & Yes & 0 & 0 \\
\hline & No & 274 & 100 \\
\hline & Total & 274 & 100 \\
\hline Type hazard sign for respondent & Calling by person & 274 & 100 \\
\hline
\end{tabular}

\section{Observational finding}

Regarding to observational result of this study all most all environmental health and safety factors in construction area such as personal protective equipment are not in the store, no enough supply, put in correct place, no sign of warning and safety rule, there was clinic in the site but had not enough supply first aid equipment, no electrical panel knockout in place, there was no training of workers, supervision of work place by safety professionals, hammers kept free of splinters, covered wall and floor opening and portable circular saws equipped with protective guard were not fulfilled within the working site, the employees are not use the necessary personal protective equipment/ worker not match with proper personal protective equipment, are not proper utilization of personal protective equipment, the ladders are safe and inspected as appropriate place, more of them use equipment lifter manual than ladder, the operating lifts are trained on the equipment.

\section{Discussion}

The study result showed that overall utilization level of personal protective equipment $192(70.1 \%)$ participant affirmed availability of one or two of the PPE, from 192(70.1\%) 115(42.0\%) were used all the time. The majority workers reason for not used PPE, 50(18.2\%) were not fill comfort, and 44(16.1\%) were not think aware of risk. Among PPE user on duty respondent above $140(51.1 \%)$ of PPE Supplied by the institution and the rest bought by workers themselves.

The availability of PPE's was not online with the type of work and hazards one was exposed at any time. In this study construction workers reported to be using the following PPE's safety boots; helmet; heavy duty glove; dust mask; ear mask; goggles; safety harness/belt but had not full supply. Participant have knowledge each PPE's is used for a different work in the construction sites, that safety boots are used to protect foot from injuries, goggle are used to protect eyes from strong light during welding and dust; overalls are used to protect one's clothing from getting dirty, helmets are used against head injuries; ear muffs are used to protect ears against excessive noise in the construction sites; safety harness/belt are used to protect workers from falling from heights. Some workers are provided with PPE and yet they were not using them especially goggles and face masks as observed in this study.

Reasons for not utilization PPE's were given by the respondent varied reasons why they did not use the available PPE's in their workplace. This study showed that some participants did not had them because they did not see any importance of them; other did not have the equipment; observation showed that some workers had PPE's, but they were not using PPE hence it influenced the increase in the use of PPE in work place. Due to these the prevalence of occupational injury in the last 12 months and 2 months un used PPE was 37(13.5\%), above half of respondent $23(8.4 \%)$ frequency of occurrence of injury in the last 12 months where one times, similar to this injury in the last 2 weeks were $11(4.0 \%)$ frequency of occurrence where one times, suffered some form of injury, did not have any used PPE's despite used PPE's participant. Among those injured workers 15(5.5\%) of them did work behavior, finger $20(7.3 \%)$ were the most injured body part of respondent. the report shows that types of accident occur in workers were hurt by struck against object $23(8.4 \%)$, struck by object $12(4.4 \%)$ and Nile injury $8(2.9 \%)$. 
The main reason of injury occurrence was due to not using PPE 11(4.0\%). Among the total injured worker 10(3.6\%) were visited hospital and 6(2.2\%) of worker were greater than 12 hours absent from work because of injury. When we compare with different study, like Study done in Gondar 38.7\% [23] and Addis Ababa 38.3\%,84.7\% [25] higher prevalence reported. So, this discrepancy may be because of our study area only one level one general contractor firm whereas study done in Addis Ababa include one to five level contractor firm and study done in Gondar nothing has been mentioned about level of contractor. And, another reason for higher prevalence sample size deference and sample population. In this study, a minimum of a year experience in construction worker is mandatory to be recruited as study participants, whereas nothing has been mentioned in both studies. In contrary study done India 22.9\% [31] and Egypt 18.4\% [24] have lower prevalence reported than our study. This difference may be safety concern; awareness and education of workers in these countries are greater than ours regarding this sector. Also, the study area also in these studies were done in big construction companies, not included small ounces, that give concern for health and safety for their workers.

Different studies report shows that male workers were significantly associated with occupational injury $[23,30]$ which alien with this study. The odds of occupational injury for male 2.85 times more likely injured than those of female workers (P-less than $0.5 \%$ ). This is may be construction work more done by male; male workers were more expose substance abuse like alcohol and chat and female workers could take their health and safety responsibility, use PPE than males. Based on our findings temporary workers were 2.92 times more likely injured than those of permanent workers $(\mathrm{p}<0.05)$. This is supported by studies conducted in Iran and Ethiopia may be explained as higher injuries reported on temporary workers were because of temporary workers do not get a chance to work for a whole year like the permanent, health and safety awareness of temporary workers was less than those of permanent workers lack experience on specific tasks and lack of job security can play an important role in occurring accidents for such workers.

This study finds out that the odds of injuries among employees who have less or equal to 4 months up to 5 years work experience were $137(50 \%)$ less compared to those who have more than $\geq$ 5 years' work experience. The possible explanation for this may be that those employees who have greater than 5 years' work experience could be accustomed to the work environment and developed false consciousness of safety which drive them not to obey with safety precautions including proper use of PPE. It might also because lack of safety awareness programs in the workplaces. This study supported by different study done Addis Ababa and Gondar [25]. Another important finding of this study was the odds of injuries among employees who earning monthly salary 960-2000 ETB were 159(58\%) less compared to those who earning $\geq 5001$ ETB. This may be explained as higher payment is related with high experience, and higher educational status, although this factor was significant in this study and workers with lower experience and educational status are usually placed in working sections involving manual contact with machines and others. According to study result showed that severities of occupational injury were among 56 injured workers $10(3.6 \%)$ visited hospitalized. Because of this $3(1.1 \%)$ of participant had lost greater than 1 month of work (1440 hours work absent). This result supported by study done in Gondar and Addis Ababa. It might also be due to construction industry is one of the hazardous and working behavior of construction industry.

\section{Conclusion}

I. Among the participant 192(70.1\%) were using only one or two of the right PPE. The extent of PPE uses especially the right ones was wanting since it was below $50 \%$ because the participate used only one type on PPE from the 110(40.1\%) user of helmet additionally $9(3.3 \%)$ used safety boots. More than $82(29.9 \%)$ of worker did not have any personal protective equipment. Most/more than 56(20.4\%) workers, who suffered some forms of injury did not have any protective equipment.

II. About 203(74.1\%) before engaged to the work and $207(75.5 \%)$ after engaged the work of participant had not been trained on PPE use and any other safety training.

III. The use of personal protective equipment in all time was found to be important factor to decrease occupational injury.

IV. Awareness and education is needed to male, higher income, higher work experience, and temporary workers because showed significant association on the occurrences of occupational injury with community group.

V. Most environmental health and safety factors in construction area such as protective equipment, sign warning and safety rule, first aid equipment, electrical panel knockout in place, training of workers, supervision of work place by safety professionals, hummers kept free of splinters were not fulfilled within the working site that may play an important role in reducing occupational injury.

\section{Recommendations}

VII. Constant awareness of all hazards, injuries, and illness associated with construction should be maintained. All sort of injuries to workers should as much as possible be minimized while on duties by using PPE.

VIII. All workers should need to use safety boots, helmet, overalls and heavy-duty gloves alongside dust masks, ear masks, goggles, safety harness/belt, and while on duty whenever necessary to minimize injuries and illness associated with construction work. 


\section{Civil Engineering Research Journal}

IX. The ministry of health, Addis Ababa health bureau, ministry of social affairs should assign occupational health and safety professionals for monitor working site to reinforce and remind the basic health and safety matters fulfillments.

X. The supervision/boss of the construction area tries to identify the needs of workers to make them satisfied by their work.

XI. The management of construction site should regularly conduct helpful safety training on a construction sites and give workers brief before commencing any work on their daily basis.

XII. NCA to contact regular monitoring of contractors to ensure safety need of workers.

\section{Acknowledgement}

My heart-felt gratitude goes to the Defense University College of Health Science of Public Health at College of Health Science library staff. We would like to extend our appreciation also for School of Public Health administrative staff, and the study participants for their cooperation and provision of valuable information.

\section{Conflict of interest}

This research article has no conflict of interest in relation to funding and material interests.

\section{References}

1. Ministry of labor and social affairs (2015) Occupational health and safety training package, Addis Ababa University.

2. Ali B (2008) Fundamental principles of occupational health and safety.

3. WHO (2009) Global Health Risks, Mortality and burden of disease attributable to selected major risks, Geneva, Switzerland?

4. Finish institute of occupational health, International labor Organization. System for collection and analysis of occupational accidents data: African Newsletter on occupational health and safety 2009: Contract No. 4-5.

5. Rantnen J (2008) Basic occupational health services. African newsletter on occupational health and safety 18(2): 29.

6. Cnnard M (2007) Perceptions of occupational health and safety A survey of stakeholder representatives in Zambia (2007).

7. Finish institute of occupational health (2008). International labor Organization. Occupational injuries African Newsletter on occupational health and safety 15(1): 3-23.

8. Ministry of labor and social affairs. Annual performance report of work-related injuries among governmental manufacturing industries Addis Ababa University, Department of occupational health and safety at work 2008. Among governmental manufacturing industries, Addis Ababa University, Department of occupational work.

9. BLS USD LO (2015) Employer-reported workplace injuries and illnesses.

10. ILO Decent Work Country Programmer 2014-15: Ethiopia/ International Labor Organization, ILO, Country Office for Ethiopia and Somalia, Addis Ababa University (2014).
11. ILO Safety and health at work: a vision for sustainable prevention: $\mathrm{XX}$ World Congress on Safety and Health at Work 2014: Global Forum for Prevention. Frankfurt, Germany/International Labor, Office. Geneva, Switzerland.

12. Tekele TMA, Kebede F (2002) Lecture Note for environmental Health Students Occupational Health, Safety, and Hygiene. University of Gondar: In collaboration with the Ethiopia Public Health Training Initiative, The Carter Center, The Ethiopia Ministry of Health, and the Ethiopia Ministry of Education.

13. WHO (2007) Workers' health: Global plan of action 2008-2017" by World Health Organization, Geneva, Switzerland.

14. ABD (2014) Environmental Impact Assessment (EIA) and Construction (2014): Review Paper. International Research Journal on Environment Science.

15. Jukka TP, Kaija H, Loke Yoke L, Kathiresan Y, Tan M, et al. (2014) Global Estimates of the Burden of Injury and Illness at Work in (2012). Journal of Occupational and Environmental Hygiene.

16. Australia SW (2015) key work health and safety statistics, Australia.

17. ILO (2014) Decent Work Country Programmers 2014-15: Ethiopia/ International Labor Organization, ILO, Addis Ababa University, Country Office for Ethiopia and Somalia.

18. ILO (2014) Safety and health at work: a vision for sustainable prevention: XX World Congress on Safety and Health at Work 2014: Global Forum for Prevention. Frankfurt, Germany/International Labour Office, Geneva, Switzerland

19. Hailemariam A (2015) Secondary Dwelling Units' Extension: The case of residential houses in Woreda 2, Akaki Kality sub city, Addis Ababa. Addis Ababa University.

20. Yitagesu Habtu (2010) assessment of magnitude and factors of occupational injury among workers in large scale metal manufacturing industry in Addis Ababa University.

21.Zewdie Aderaw, Dagnew Engdaw, Tadesse (2011) Determinants of Occupational Injury: A Case Control Study among Textile Factory Workers in Amhara Regional State; Journal of Tropical Medicine.

22. Zhao lin Xia, Theodore K, Gary S, Jin liang Zhu, Hua Fu, et al. (2000) Fatal Occupational Injuries in a New Development Area in the People Republic of China. JOEM September 42(9): 917-922.

23. Takele Tadesse, Abera Kumie (2007) Prevalence and factors affecting work-related injury among workers engaged in Small and MediumScale Industries in Gondar woreda, north Gondar zone Amhara Regional State, Ethiopia; Ethiop Journal of Health Development.

24. Ministry of Labour and Social Affairs. Labour statistics annual bulletin department of Labour Addis Ababa (2002).

25. Asim S, Takiar R, Ramendraetal N (2004) Anaccident-risk assessment study of temporary piece rate workers, National Institute of Occupational Health India. Occupational Medicine Division, Industrial Health 42(2): 240-255.

26. Strong L, Zimmerman FI (2005) Occupational injury and absence from work among African American Hispanic and non-Hispanic white workers in the national longitudinal survey of youth. American Journal of Public health 95(7): 1226-1232.

27. Etal SP (1992) Occupational injury. The injury fact book. Pp: 114-194.

28. Bereto SM, Swerdlows AJ, Smith PGA (1998) Nested case control study of fatal work-related injuries among Brazilian Steel workers. BMJ.

29. Osman Yiha, Kumie A (2010) Assessment of occupational injuries in Tendaho Agricultural Development S C, Afar Regional State, Ethiop J Health Dev. 


\section{Civil Engineering Research Journal}

30. Nearkasen C, Marie J, Lahoucineetal B (2002) Relationships between some individual characteristics and occupational accidents in the construction industry: a case-control study; Journal of Occupational Health 44(3):131-139.

31. Hardeep Rai Sharma, Susila Appadurai, Mamo Wubshet a, Tadesse $\mathrm{T}$ (2008) Occupational exposures and related health effects among construction workers Ethiopia. Journal of Health Biomedical Science 1(1).
32. Central Statistical Authority. Summary and statistical reports of population and housing census Addis Ababa (2007).

33. Asim Saha, Anjali Nag, Pranab Kumar Nag (2006) Occupational injury proneness in Indian women: A survey in fish processing industries. Journal of Occupational Medicine BioMed Central and Toxicology.

\section{Your next submission with Juniper Publishers will reach you the below assets}

- Quality Editorial service

- Swift Peer Review

- Reprints availability

- E-prints Service

- Manuscript Podcast for convenient understanding

- Global attainment for your research

- Manuscript accessibility in different formats

( Pdf, E-pub, Full Text, Audio)

- Unceasing customer service

Track the below URL for one-step submission https://juniperpublishers.com/online-submission.php 